\title{
PENGARUH PEMBERIAN SEDIAAN MIKROEMULSI EKSTRAK DAUN KARAMUNTING (Rhodomyrtus tomentosa [Aiton] Hassk) DAN MIKROEMULSI EKSTRAK BIJI PINANG (Arace Catechu Linnaeus) TERHADAP PENURUNAN KADAR GULA DARAH PUASA PADA TIKUS PUTIH JANTAN YANG DIINDUKSI ALOKSAN
}

\author{
Brillyanti Monic $^{1}$ Amilia Kurnia $^{2}$ Didit Prasetyo $^{3}$ \\ ${ }^{123}$ STIKes Borneo Cendekia Medika Pangkalan Bun \\ 1email : brillyantimonica@yahoo.co.id, ${ }^{2}$ email : ameliakurnia26@gmail.com, ${ }^{3}$ email : \\ diditprasetyo78@gmail.com
}

\begin{abstract}
ABSTRAK
Karamunting (Rhodomyrtus tomentosa [Aiton] Hassk) merupakan tumbuhan khas Kalimantan yang secara empiris digunakan masyarakat sebagai tumbuhan obat penyakit diabetes melitus. Senyawa dalam daun karamunting yang dapat menurunkan kadar gula darah adalah alkaloid, flavonoid dan tanin. Tumbuhan obat yang juga sering di manfaatkan oleh masyarakat Kalimantan adalah tumbuhan pinang yang sudah digunakan secara turun temurun (Sada dan Rosye, 2010).Biji pinang memiliki khasiat sebagai tanaman antidiabetik yang dapat menurunkan hiperglikemia. Biji Pinang mengandung senyawa alkaloid arekolin yang memiliki aktivitas antihiperglikemik. Penelitian ini bertujuan untuk mengetahui pengaruh pemberian mikroemulsi ekstrak daun karamunting $244 \mathrm{mg} / 200 \mathrm{gr}$ dan mikroemulsi ekstrak biji pinang untuk menurunkan kadar gula darah pada tikus putih jantan galur wistar yang diinduksi aloksan.Penelitian ini bersifat eksperimental murni dengan menggunakan 24 ekor hewan uji yang diinduksi aloksan $20 \mathrm{mg} / 200 \mathrm{mg}$ secara intraperitoneal. Hewan uji tikus dibagi menjadi 6 kelompok perlakuan yaitu kelompok kontrol positif mikroemulsi glibenklamid, kelompok kontrol negatif mikroemulsi plasebo serta kelompok perlakuan mikroemulsi ekstrak daun karamunting. Pengukuran kadar Gula Darah Puasa (GDP) dilakukan pada hari ke- 0 , hari ke-3 (GDP setelah induksi aloksan) dan GDP hari ke-10 (GDP setelah perlakuan). Persen penurunan kadar GDP dianalisis secara statistika dengan taraf kepercayaan $95 \%$. Hasil uji statistika menyatakan ada perbedaan signifikan antara kelompok kontrol positif dengan kelompok kontrol negatif dengan nilai sig. 0,00. Perbedaan signifikansi juga terjadi pada kelompok kontrol negatif dengan kelompok perlakuan mikroemulsi ekstrak daun karamunting dengan nilai sig. 0,00. Sedangkan pada kelompok kontrol positif dan kelompok mikroemulsi ekstrak daun karamunting tidak ada perbedaan signifikan dengan nilai sig. 0,24, sehingga dapat disimpulkan bahwa mikroemulsi ekstrak daun karamunting dapat menurunkan kadar gula darah yang sebanding dengan kontrol positif mikroemulsi glibenklamid.
\end{abstract}

Kata kunci : Mikroemulsi, Karamunting, Biji Pinang, Aloksan, Diabetes Melitus. 


\title{
THE INFLUENCE OF THE PREPARATION MIKROEMULSI EXTRACT LEAVES KARAMUNTING (RHODOMYRTUS TOMENTOSA AITON HASSK) AND MIKROEMULSI EXTRACT OF SEEDS PINANG (ARACE AELIG CATECHU LINNAEUS) TO A DECREASE IN BLOOD SUGAR LEVELS FAST IN MICE INDUCED ALOKSAN WHITE MALE
}

\begin{abstract}
Karamunting ( rhodomyrtus tomentosa aiton hassk) is herbs typical of borneo are empirically used the community as herbs drug of diabetes mellitus. Compound in the leaves karamunting that can be lowered blood sugar were an alkaloid, flavonoid and tannin. Herbs a drug that also often in use by the community kalimantan s the plant pinang that had been used in hereditary (sada and rosye, 2010). Areca nut seeds have efficacy as a plant antidiabetik hiperglikemia that can be lowered. Areca nut seeds compounds containing an alkaloid arekolin having antihiperglikemik activity. Research aims to understand the influence of the provision of mikroemulsi extract leaves karamunting 244mg / $200 \mathrm{gr}$ and mikroemulsi an extract of seeds pinang to lower the levels of blood sugar in mice white male that is induced aloksan galur wistar This research is pure experimental using the 24 animals induced alloxan 20mg/200 mg in intraperitoneal The fit and proper test animals mice divided into 6 the treatment group is positive control group of glibenklamid mikroemulsion, the negative control group of placebo mikroemulsion and the mikroemulsion karamunting leaf extract. Measurement blood sugar on the day-0, day-3 (after alloxan induction) and day-10 (after treatment). Reduction percent of blood sugar level was statistically analyzed with 95\% confidence level. Statistical test results was a significant difference between positive control group to negative control group of value sig 0,00. Significant difference also happens to negative control group to microemulsion karamunting leaf extract group. While in positive control group and microemulsion karamunting leaf extract there are no significant difference with sig 0,24. So it can be concluded that microemulsion karamunting leaf extract comparable with positive control of glibenclamide microemulsion to lowered blood sugar level.
\end{abstract}

Key word: Microemulsion, Karamunting Leaf, Areca Nut, Aloxan, Diabetic Melitus

\section{PENDAHULUAN}

Internasional Diabetic Federation (IDF) menerangkan bahwa prevalensi global penderita DM pada tahun 2017 mencapai 424,9 juta kasus dan diperkirakan akan meningkat hingga 628,6 juta kasus pada tahun 2045. Indonesia merupakan negara yang menempati urutan ke 6 dengan 10,3 juta penderita DM setelah Cina, India, Amerika Serikat, Brazil dan Mexico'. Diabetes Melitus yang tidak terkontrol dengan baik dapat menimbulkan komplikasi akut maupun kronis seperti neuropati, nefropati, retinopati, Penyakit Jantung Koroner (PJK), stroke, hipertensi, gangguan pada hati, penyakit paru serta gangguan saluran cerna serta infeksi ${ }^{2}$. Untuk mencegah komplikasi 
kronik, diperlukan pengendalian DM yang baik. Secara spesifik penatalaksanaan DM memiliki tujuan utama, yaitu menjaga kadar glukosa darah dalam kisaran normal serta mencegah atau meminimalkan kemungkinan terjadinya komplikasi diabetes $^{3}$. Terdapat dua pendekatan terapi dalam penatalaksanaan DM, yakni terapi farmakologi dan nonfarmakologi.

Salah satu obat tradisional yang digunakan untuk diabetes melitus adalah karamunting (Rhodomyrtus Tomentosa [Aiton] Hassk). Karamunting (Rhodomyrtus Tomentosa [Aiton] Hassk) merupakan tumbuhan obat yang harus dikembangkan karena telah diteliti sebagai tumbuhan yang memiliki beberapa khasiat ${ }^{4}$. Bagian tumbuhan obat karamunting (Rhodomyrtus Tomentosa [Aiton] Hassk) yang banyak dimanfaatkan oleh masyarakat adalah pada bagian daunnya. Daun karamunting (Rhodomyrtus Tomentosa [Aiton] Hassk) mengandung senyawa golongan fenol, saponin, tanin, steroid, terpenoid dan flavonoid ${ }^{5}$. Biji pinang merupakan tanaman tradisional yang sering di manfaatkan masyarakat umumnya untuk pengobatan tradisional. Biji pinang memiliki khasiat sebagai tanaman antidiabetik yang dapat menurunkan hiperglikemia. Biji Pinang mengandung senyawa alkaloid arekolin yang memiliki aktivitas antihiperglikemik.

Penelitian ini bertujuan untuk Mengukur pengaruh pemberian mikroemulsi ekstrak daun karamunting (Rhodomyrtus Tomentosa [Aiton] Hassk) dan ekstrak biji pinang (Areca Nut) terhadap kadar gula darah puasa pada tikus yang telah diinduksi aloksan.

\section{METODE PENELITIAN}

Penelitian ini merupakan penelitian eksperimen laboratorium

\section{Alat dan bahan}

Sonde oral, kandang tikus beserta tempat makan dan minum, timbangan analitik (Centaurus Scale), timbangan analog, sentrifuse (Wina Instrument), tabung sentrifuse, alat pengambil darah (mikrohematokrit non heparin), rak tabung, beaker glass (Herma), gelas ukur, corong, labu takar, erlenmeyer, tabung reaksi, hotplate magnetic stirer (Wina Instrument), ayakan, pisau, blender, spektrofotometer UV-Visible (Photometer $5010_{\mathrm{V} 5_{+}}$), kertas saring, $\mathrm{pH}$ indikator universal, batang pengaduk, ultra turrax, partical size analyzer (Horiba SZ-100), morter dan stamper.

Bahan Penelitian. Bahan Uji : Daun karamunting (Rhodomyrtus tomentosa (Aiton) Hassk) dan biji pinang (Arace Catechu Linnaeus) . Bahan penginduksi : Bahan penginduksi yang digunakan adalah larutan WFI aloksan $\left(\mathrm{C}_{4} \mathrm{H}_{2} \mathrm{~N}_{2} \mathrm{O}_{4}\right)$. Bahan pembanding : Glibenklamid. Bahan habis pakai dan Bahan Kimia : Pakan standar, Etanol $70 \%$, etanol $96 \%, \mathrm{H}_{2} \mathrm{SO}_{4}$, $\mathrm{VCO}$ (Virgin Coconut Oil), span 80, tween 80, $\mathrm{Na}_{2} \mathrm{HPO}_{4}, \quad \mathrm{KH}_{2} \mathrm{PO}_{4}, \mathrm{NaCl}$, gliserin, natrium benzoat, asam sitrat, asam asetat anhidrat, kloroform, pereaksi dragendorf, serbuk $\mathrm{Mg}, \mathrm{HCl}, \mathrm{FeCl}_{3}$ dan aquadestilata. Bahan pemeriksaan kadar glukosa darah: Larutan reagensia GOD-PAP, larutan sampel (serum darah) dan larutan standar. 


\section{Prosedur kerja}

Pembuatan ekstrak daun karamunting dan biji pinang. Daun karamunting dan biji pinang yang telah diserbukkan ditimbang kemudian dimasukkan ke dalam bejana maserasi. Direndam $200 \mathrm{mg}$ serbuk daun karamunting dengan etanol $70 \%$ hingga seluruh serbuk terendam. Bejana maserasi ditutup alumunium foil serta dijauhkan dari cahaya matahari langsung. Perendaman dilakukan selama 5 hari. Setelah itu, dilakukan penyaringan untuk memisahkan ampas dan filtrat. Filtrat yang telah dipisahkan kemudian diuapkan sehingga diperoleh ekstrak kental.

Uji efektivitas antidiabetes. Pengujian efektivitas antidiabetes sediaan mikroemulsi dilakukan dengan menggunakan sampel penelitian yang mengalami diabetes melitus setelah penginduksian aloksan. Sebanyak 24 ekor tikus yang mengalami DM dibagi menjadi 6 kelompok dengan perlakuan yang berbeda, diantaranya sebagai berikut:

a. Kelompok I/ Kontrol positif : Pada hari ke 4-10 hewan uji diberi perlakuan 0,09 mg/ $200 \mathrm{gr} / \mathrm{hari}$ mikroemulsi glibenklamid. b. Kelompok II/ Kontrol negatif : Pada hari ke 4-10 hewan uji diberi perlakuan mikroemulsi plasebo.

c. Kelompok III/ Kelompok Perlakuan: Pada hari ke 4-10 hewan uji diberi perlakuan sediaan mikroemulsi ekstrak daun Karamunting dan mikroemulsi biji pinang.

\section{HASIL DAN PEMBAHASAN}

Pembuatan esktrak etanol daun karamunting dan biji pinang dilakukan dengan cara maserasi. Metode ini dipilih karena proses pengerjaanya yang mudah serta peralatan yang digunakan sederhana. Pengujian efektivitas antidiabetes sediaan mikroemulsi dilakukan dengan menggunakan sampel penelitian yang mengalami diabetes melitus setelah penginduksian aloksan. Sebanyak 24 ekor tikus yang mengalami DM dibagi menjadi 6 kelompok dengan perlakuan yang berbeda.

Tabel 1. Rata-rata Kadar GDP (mg/ dL) Hewan Uji serta persentase kenaikan dan penurunan GDP pada semua kelompok perlakuan

\begin{tabular}{|c|c|c|c|c|c|}
\hline \multirow[t]{2}{*}{$\begin{array}{l}\text { Kelo } \\
\text { mpok }\end{array}$} & $\begin{array}{l}\text { GDP } \\
\text { hari } \\
\text { ke }-0\end{array}$ & $\begin{array}{l}\text { GDP } \\
\text { hari } \\
\text { ke }-3\end{array}$ & $\begin{array}{c}\% \\
\text { Kenai } \\
\text { kan } \\
\text { GDP }\end{array}$ & $\begin{array}{c}\text { GDP } \\
\text { hari ke } \\
-10\end{array}$ & $\begin{array}{c}\% \\
\text { Pen } \\
\text { urun } \\
\text { an } \\
\text { GDP }\end{array}$ \\
\hline & $\begin{array}{l}X \pm \\
S D\end{array}$ & $\begin{array}{l}X \pm \\
S D\end{array}$ & $\begin{array}{l}X \pm \\
S D\end{array}$ & $\mathrm{X} \pm \mathrm{SD}$ & $\begin{array}{l}X \pm \\
S D\end{array}$ \\
\hline Kontr & 107 & 159,2 & 49,22 & 102,25 & 35,8 \\
\hline $\mathrm{ol}$ & \pm & $5 \pm$ & \pm & $\pm 3,30$ & $0 \pm$ \\
\hline
\end{tabular}




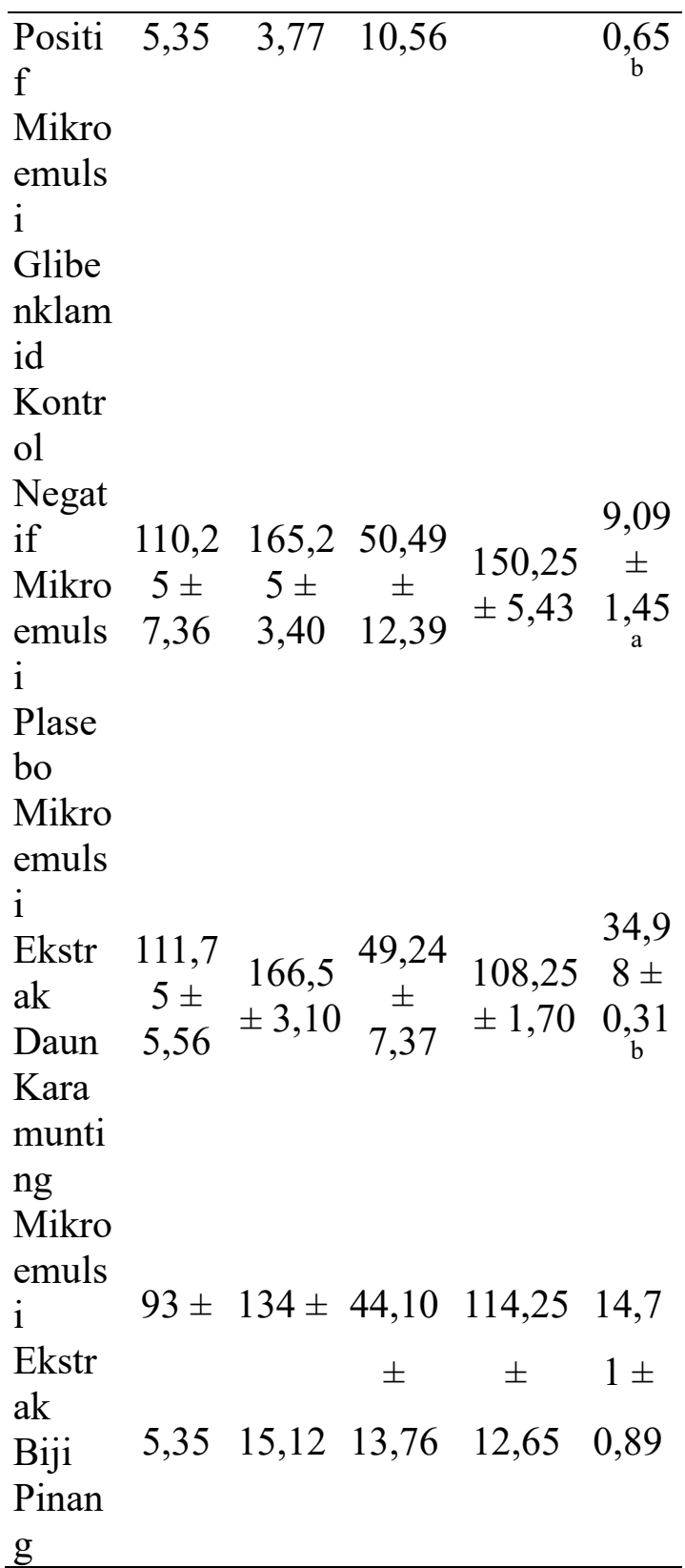

Kadar GDP pada normal yaitu 90 $\mathrm{mg} / \mathrm{dL}$. Nilai ini didapatkan dari hasil rata - rata kadar GDP pada semua hewan uji $(n=12)$. Kadar GDP pada tikus normal pada penelitian ini selanjutnya di jadikan acuan (GDP hari
nol/GDP H-0) adanya peningkatan atau penurunan kadar GDP dalam serum hewan uji. Hewan uji diinduksi aloksan dengan mekanisme metabolisme oksidasi reduksi yang menghasilkan radikal bebas dan mengakibatkan kerusakan sel beta pankreas. Penggunakan dosis aloksan $20 \mathrm{mg} / 200$ gr dipilih berdasarkan penelitian Rosdiani (2013) bahwa sel sel beta pankreas pada hewan uji tikus putih jantan masih dapat mensekresikan insulin dan ini menunjukan situasi kondisi kearah penyakit DM tipe 2.

Hewan uji yang dinyatakan mengalami hiperglikimia setelah proses induksi aloksan dibagi menjadi 3 kelompok perlakuan yaitu kelompok kontrol positif, kontrol negatif, kontrol perlakuan mikroimulsi ekstrak daun karamunting, mikroemulsi ekstrak biji pinang. Semua kelompok uji dilakukan perlakuan selama 7 hari hingga hari ke sepuluh (H-10). Karena untuk menghindari regenerasi sel beta pankreas yang terjadi pada waktu 12 hari setelah induksi aloksan. Pemberian sediaan dilakukan secara perorang menggunakan sonde untuk hewan uji 
tikus dosis pemberian sediaan di sesuaikan dengan berat badan hewan uji. Setiap kelompok yang di beri perlakuan berbeda pada $\mathrm{H}-10$ di lakukan kembali pengambilan darah untuk mengetahui kadar glukosa darah puasa hari ke sepuluh (GDP H-10). Selisih nilai antara GDP $\mathrm{H}-3$ dan GDP $\mathrm{H}-10$ adalah presentase penurunan kadar GDP setelah perlakuan. Berdasarkan tabel 1 menunjukan persen penurunan kadar GDP hewan uji.

Dapat disimpulkan bahwa formulasi sediaan mikroemulsi ekstrak daun karamunting dan mikroemulsi ekstrak biji pinang dengan kontrol negatif placebo berbeda signifikan, artinya formulasi mikroemulsi ekstrak biji pinang mempunyai potensi yang efektif untuk menurunkan kadar glukosa darah puasa.

\section{KESIMPULAN}

Pemberian Sediaan mikroemulsi ekstrak daun karamunting (Rhodomyrtus Tomentosa [Aiton] Hassk) 244mg/200g dapat menurunkan kadar gula darah puasa sebesar $34,98 \%$ pada tikus putih jantan yang diinduksi aloksan dan sedian mikroemulsi ekstrak biji pinang dapat menurunkan kadar gula darah puasa tikus yang diinduksi aloksan sebesar $14,71 \%$.

\section{DAFTAR PUSTAKA}

IDF, 2017. International Diabetic Atlas. Eight Edition. International Diabetic Federation.

Ndraha, Suzanna, 2014. Diabetes Melitus Tipe 2 dan Tatalaksana Terkini. Jurnal Medicinus, Vol 27, No.2. Jakarta.

Depkes RI, 2005. Pharmaceutical Care untuk Penyakit Diabetes Mellitus. Departemen Kesehatan Republik Indonesia, Jakarta.

Ramadhani, Mira Surya., Laily, Nur., Mahmudah. 2013. Potensi Tumbuhan Karamunting Untuk Penyakit Defisiensi. Universitas Lambung Mangkurat. Banjarbaru.

Sinata, Novia., Arifin, Helmi. 2016. Antidiabetes dari Fraksi Air Daun Karamunting (Rhodomyrtus Tomentosa (Ait.) Hassk.) terhadap Kadar Glukosa Darah Mencit Diabetes. Jurnal Sains Farmasi \& Klinis. Ikatan Apoteker Indonesia. Sumatera Barat. 
